Review

\title{
Anthrax Toxins in Context of Bacillus anthracis Spores and Spore Germination
}

\author{
Christopher K. Cote * and Susan L. Welkos
}

United States Army Medical Research Institute of Infectious Diseases (USAMRIID), Bacteriology Division, 1425 Porter Street, Fort Detrick, Frederick, MD 21702-5011, USA; E-Mail: susan.1.welkos.civ@mail.mil

* Author to whom correspondence should be addressed; E-Mail: christopher.k.cote.civ@mail.mil; Tel.: +1-301-619-4936; Fax: +1-301-619-2152.

Academic Editor: Shihui Liu

Received: 29 July 2015 / Accepted: 11 August 2015 / Published: 17 August 2015

\begin{abstract}
The interaction of anthrax toxin or toxin components with B. anthracis spores has been demonstrated. Germinating spores can produce significant amounts of toxin components very soon after the initiation of germination. In this review, we will summarize the work performed that has led to our understanding of toxin and spore interactions and discuss the complexities associated with these interactions.
\end{abstract}

Keywords: anthrax; Bacillus anthracis; spores; anthrax toxins; PA; germination

\section{Toxins Are Crucial for Bacillus anthracis Pathogenesis}

Bacillus anthracis, a gram-positive spore-forming bacterium, is the etiologic agent of anthrax [1-4]. It is important to note that, outside of the laboratory, the spore is the only infectious form of B. anthracis [5-8]. In most cases of anthrax acquired by inhalation, the spores are thought to be transported from their site of deposition in the lungs to regional lymph nodes where they germinate and outgrow into the vegetative bacilli [9-15]. The bacilli multiply within the lymph nodes and are then released, rapidly spread systemically, and produce large amounts of the anthrax toxins. Germination near the entry site or in epithelial/nonlymphoidal tissues has also been demonstrated though the significance of these events is uncertain [8,16-19]. B. anthracis spore germination and subsequent disease progression has been reported to be substantially different in cutaneous models of disease [20-22]. 
Nevertheless, evidence exists for toxin production during the earliest stages of spore germination, as will be reviewed.

In a natural setting anthrax is predominantly a disease of herbivores feeding on vegetation from fields contaminated with $B$. anthracis spores. Carnivores can become exposed to/infected by $B$. anthracis when feeding on animals which previously died of anthrax [23-25]. In humans, there are three major forms of anthrax as delineated by the route of spore exposure, cutaneous, gastrointestinal and inhalational [26].

The large majority of reported anthrax cases are cutaneous infections. Although cutaneous infections can be fatal, they are more typically self-limited, with mortality rates in untreated cases of about 20\% [27-29]. A comparatively new form of human disease, injectional anthrax, has been observed among intravenous drug users, i.e., heroin addicts in Western Europe [29-34]. This disease can range from cutaneous/intradermal to septicemic anthrax [32]. Gastrointestinal infections in humans have been reported, but are considered rare [35-38]. The biodefense community is most concerned with the third major form of disease, inhalational anthrax, due to the potential ease of aerosol exposure to lethal doses of spores, non-specific clinical symptoms, and rapid progression; if left untreated it has a mortality rate approaching $100 \%[39,40]$. Thus, early diagnosis of inhalational anthrax can be very challenging and unless there is a high index of suspicion, the disease can rapidly progress to a stage which is no longer treatable with antibiotics. All of these forms of infection are initiated by the introduction of ungerminated spores into the susceptible host. Ultimately, fatal anthrax is the result of acute intoxication and massive bacteremia [39].

The overwhelming effects of anthrax lethal and anthrax edema toxins are well characterized and have been reviewed extensively [13,41-45]. The EF is a calmodulin-dependent adenylate cyclase [46,47] and the LF is a zinc-matalloproteinase known to induce MAPKK cleavage $[48,49]$. Both the EF and LF require the protective antigen (PA) component, encoded by the pagA gene, to facilitate translocation into the host cells cytosol where they can act [50-53]. Importantly, the PA protein has been shown to elicit a strong and protective immune response and accordingly has served as the primary vaccine antigen in effective human anthrax vaccines [54]. The exact mechanisms and interactions of these toxins and individual toxin components are described in detail in numerous review articles $[41-43,55,56]$. Our focus will be to summarize the interactions of these toxins and toxin components with $B$. anthracis spores. The potential ramifications of these interactions will be described.

\section{Ungerminated Bacillus anthracis Spores Contain Detectable Levels of PA and Are Affected by Anti-PA Antibodies}

One of the earliest reports of the phenomena resulting from spore and anti-toxin antibody interactions was published in 1996. Stepanov et al. demonstrated that immunoglobulins arising from vaccination with the live attenuated ST-1 vaccine strain had anti-toxin effects as expected, but also had effects on B. anthracis spores [57]. These observations suggested that the immune response resulting from such a vaccination could prevent lethal intoxication but also potentially alter the earliest stages of the disease pathogenesis (i.e., when the ungerminated spores are first introduced into the host). IgM collected from rabbits vaccinated with ST-1 strain opsonized germinating spores resulting in a significantly increased rate of phagocytosis. Antibodies to the anthrax toxin components also inhibited spore germination, whereas other presumably unrelated antibodies (i.e., antibodies induced by Clostridium botulinum, 
Francisella tularensis, Yersinia pestis, and measles virus) did not inhibit spore germination. They demonstrated that anti-staphylococcal antibodies inhibited germination, but maintained that this finding supported the existence of significant similarities between B. anthracis and Staphylococcus bacteria. These results clearly set the stage for further characterization of vaccine-induced antibody and spore interactions, in particular the potential ability of anti-toxin antibodies to modify spore germination and subsequent host-interactions. This concept was novel because, based upon previous understanding of the anthrax life cycle, significant amounts of toxin should not be present until vegetative cell replication was well underway, as described in the previous section. It should be noted that since toxin-based vaccines effectively protect animals against infection with $B$. anthracis and not just against intoxication, it follows logically that the toxins (and presumably the immune response to them) would have major roles from the initial stages of infection [58].

Later work clearly demonstrated that ungerminated B. anthracis spores contained a detectable level of toxin components (at least PA). This was demonstrated initially by electron microscopy, SDS PAGE gel analyses, and subsequently additional sensitive assays as described below [59-61]. Whether this spore-associated PA is an innate product of the spores or merely represents an artifact from sporulation conditions and/or spore purification procedures has not been fully resolved. It was, however, clearly shown that the amount of PA on ungerminated spores was sufficiently adequate to interfere with spore germination and influence opsonization of the spores in in vitro macrophage assays performed in the presence of anti-PA antibodies. These antibody interactions were hypothesized to potentially impact the earliest stages of infection soon after the first introduction of spores into the host.

\section{Anthrax Toxin Components Are Produced by Germinating Spores}

In order to initiate disease, ungerminated $B$. anthracis spores that were introduced into the host must germinate and replicate. The transition from ungerminated spore to germinated cell is a complex cascade of events that can occur very rapidly in a suitable environment [62-65]. An early publication by Guidi-Rontani et al., detailing spore-macrophage interactions early after infection, demonstrated that the LF component of anthrax toxin was produced by germinating spores associated with macrophages within $3 \mathrm{~h}$ post-infection [66]. This was the first account demonstrating toxin component production at such an early time point.

Electron microscopy studies have clearly identified an association of PA and germinating spores [61,67]. The morphologically distinct germinated spores appeared to interact less with anti-PA antibodies than ungerminated spores [59]. This observation led to experiments to quantify PA production by germinating spores. Defined minimal germination induction solutions were used in order to induce germination but not allow outgrowth or replication of bacilli. Media used in these studies included AI ( $L$-alanine and inosine) and AAC ( $L$-alanine, adenosine, and casamino acids) [59]. AI will not permit vegetative growth even after $24 \mathrm{~h}$ incubations and AAC medium (more complex/metabolically complete than AI) will not permit replication during short term assay periods [59] but will allow vegetative outgrowth after extended incubations [68]. Spores exposed to AAC medium were lysed and the RNA extracted. The $p a g A$ transcript was detected by reverse-transcription PCR analysis after only 15 min of exposure to AAC. 
Additionally, an immunomagnetic electrochemiluminescense assay (ECL) was employed in these studies to detect PA production using anti-PA antibodies, as described previously [59,69]. ECL utilizes antibodies (in this case a pool of monoclonal anti-PA antibodies) conjugated to microbeads. Detection was then achieved by the addition of ruthenium labeled polyclonal rabbit anti-PA antibodies. It was determined that the limit of detection under these conditions was approximately $100 \mathrm{pg} / \mathrm{mL}$ [59]; other similar ECL assays have achieved sensitivities in the femtogram range, demonstrating the very high sensitivity that can be achieved with such detection assays [69]. PA was detected on spores incubated in AAC medium within $60 \mathrm{~min}$. The data acquired using the less nutritive AI medium suggested that PA could be observed on these germinating spores within a $2 \mathrm{~h}$ incubation period. The fact that the amount of PA found on the germinating spores appeared to correlate with the complexity of the medium, was further proof that germinating spores can produce detectable levels of toxin components. Supernatants collected from germinating spores were also tested for the presence of PA. Regardless of the medium used, AI or AAC, detectable levels of PA were observed in the supernatants. These findings indicated that spores can potentially synthesize and secrete or release these toxin components during early stages of germination.

\section{The Interactions among Bacillus anthracis Spores, Toxins and Host Macrophages Are Complex}

The interactions among spores, toxins and host cells can be complex in nature. The deleterious effects of anthrax toxins on the host immune response have been well documented [55]. In the traditional anthrax paradigm, systemically replicating vegetative bacilli produce dramatically enhanced quantities of anthrax toxins during the later stages of infection. The toxins and/or toxin components interact with anthrax toxin receptors on the cell surface and are subsequently translocated into the cytosol of the cell. To date, there are two known anthrax toxin receptors, TEM8 [70] and CMG2 [71,72]. Other work has documented that the LDL receptor-related protein LRP6 and the $\beta-1$ integrin can impact anthrax toxin receptor function and that complexes containing $\beta 1$-integrin can also act independently as low affinity toxin receptors [73,74]. Anthrax toxins have been shown to negatively impact macrophages [75-84], neutrophils [85-87], dendritic cells [20,88-90], and other host cell types [91-93]. In 2005, Banks et al. presented a model which suggests that after phagocytosis of spores by host cells (i.e., macrophages), the spore can germinate and begin producing toxins within the phagolysosome [94]. Anthrax toxin receptors can be located on the inside of the phagolysosomes [94,95], and thus are available to interact with the toxins secreted by the newly germinated spores. The toxin components LF and EF are then translocated into the cell cytosol, resulting in intoxication by the germinating spores from within the macrophage and the subsequent downstream events described above. Thus, this model highlighted alternate interactions that could potentially take place among spores, toxins and host cells.

It was previously demonstrated that macrophages were important in limiting the ensuing anthrax infection in a mouse model of anthrax. In these studies mice that were chemically depleted of macrophage populations were significantly more susceptible to anthrax initiated by the intraperitoneal injection or inhalation of spores $[67,96]$. Conversely, mice that received supplementary treatments with tissue culture macrophage-like cells (RAW264.7 cells) or mice that received starch as an eliciting agent for native macrophage recruitment were significantly more likely to survive challenge with lethal doses of spores [96]. Furthermore, it was demonstrated that treatment with RAW264.7 cells harboring an 
inactivated anthrax toxin receptor, protected the mice from $B$. anthracis infection at rates even greater than did treatment with wild-type RAW264.7 cells [97], further documenting the interplay between spore infections and intoxications. Specifically these results appear to demonstrate both the susceptibility of macrophages to the lethal effects of toxin produced by the germinating organisms and paradoxically the ability of macrophages to protect the host against $B$. anthracis infection.

Hanna et al. demonstrated that macrophage depletion results in mice becoming more resistant to intoxication. In these studies mice were challenged with anthrax lethal toxin alone and did not initiate an infection [98]. This report suggested a role for macrophages in facilitating infection or intoxication (i.e., the Trojan horse concept) $[14,15,98]$. Collectively these data as well as more recent studies may contribute towards explaining the basis of the long-observed inverse correlation between sensitivity to infection and to toxin challenge in some animals $[99,100]$. The presence of increased numbers of macrophages might protect better against spore infection but increase sensitivity to toxin. The potential role(s) of other host cells types and other bacterial factors in anthrax mortality remains to be completely elucidated and is beyond the scope of this review.

Thus, taken together, these data demonstrate several scenarios that might be observed during the pathogenesis of anthrax. It is important to note that these situations are rarely synchronous and their potential outcomes can vary depending on many factors including strain of mouse, strain of B. anthracis, challenge route/site, or cell type(s) studied. Additionally, even in the same model system (i.e., in vitro macrophage assay) there can be variables which can alter the outcome. Such variables include the number of spores phagocytosed by the cell, and the proportions of spores which germinate after phagocytosis and which survive the anti-bacterial environment of the phagolysosome [7,97]. For example, in a single macrophage with a relatively heavy spore burden, some spores may remain ungerminated, others may germinate and succumb to killing prior to outgrowth, and another subpopulation may germinate (potentially causing intoxication of the macrophage), outgrow, and escape from the cell.

Antibodies directed against spore-specific antigens have been shown to be opsonic [101-104]. Similar effects of anti-PA antibodies on the spore macrophage interactions have also been documented. In tissue culture assays, anti-PA antibodies are opsonic and significantly augment the rate of spore phagocytosis by macrophages as well as enhance the sporicidal activity of the macrophages. These studies were performed using ungerminated spores as well as germinated spores. Interestingly, the opsonic and augmented killing effects were generally lost approximately $24 \mathrm{~h}$ after spore germination, further supporting the concept that spores rapidly release PA upon germination [60,61]. An additional and separate spore effect attributed to anti-PA antibodies has been the demonstration that anti-PA antibodies inhibit germination of $B$. anthracis spores in vitro. This was demonstrated by using a semi-automated fluorescence-based germination assay, by showing antibody-mediated inhibition of spore stainability in the presence of germinant, and by examining spore refractility using phase contrast microscopy [59,105]. The significance of these in vitro and in situ antibody-mediated effects in the immune responses of the host animal to spore challenge remains to be determined.

Our goal in this brief review has been to highlight the complexity as well as the importance of spore, toxin, and host interactions. Anti-toxin antibodies undoubtedly play an essential role in protecting vaccinated individuals from a lethal anthrax infection. However, the data reviewed herein also help to reinforce the concept that these anti-PA antibodies (and conceivably anti-LF or anti-EF antibodies) likely 
play a role in infection control very soon after the introduction of spores into the host. Because of emerging and engineered threats it is crucial to continue investigating novel vaccine strategies to protect the warfighter and potentially civilian populations. A better understanding of these early interactions may hold the key to such strategies.

\section{Acknowledgments}

Opinions, interpretations, conclusions, and recommendations are those of the authors and are not necessarily endorsed by the U.S. Army.

\section{Author Contributions}

Christopher K. Cote and Susan L. Welkos contributed to the research and the writing of the manuscript.

\section{Conflicts of Interest}

The authors declare no conflict of interest.

\section{References}

1. Koch, R. The aetiology of anthrax based on the ontogeny of the anthrax bacillus. Beirt. Biol. Pflanz. 1877, 2, 277-282.

2. Turnbull, P.C.B. Introduction: Anthrax history, disease, and ecology. In Anthrax; Koehler, T.M., Ed.; Springer-verlag: Berlin, Germany, 2002; Chapter 1, pp. 1-19.

3. Cote, C.K.; Chabot, D.J.; Scorpio, A.; Blank, T.E.; Day, W.A.; Welkos, S.L.; Bozue, J.A. Bacillus anthracis: Agent of bioterror and disease. In Microorganisms and Bioterrorism; Anderson, B., Friedman, H., Bendinelli, M., Eds.; Springer: New York, NY, USA, 2006; pp. 83-111.

4. Mock, M.; Fouet, A. Anthrax. Ann. Rev. Microbiol. 2001, 55, 647-671.

5. Turnbull, P. Anthrax in Humans and Animals, 4th ed.; WHO Press: Geneva, Switzerland, 2008.

6. Cote, C.K.; Bozue, J.; Twenhafel, N.; Welkos, S.L. Effects of altering the germination potential of Bacillus anthracis spores by exogenous means in a mouse model. J. Med. Microbiol. 2009, 58, 816-825.

7. Cote, C.K.; Welkos, S.L.; Bozue, J. Key aspects of the molecular and cellular basis of inhalational anthrax. Microbes Infect. 2011, 13, 1146-1155.

8. Weiner, Z.P.; Glomski, I.J. Updating perspectives on the initiation of Bacillus anthracis growth and dissemination through its host. Infect. Immun. 2012, 80, 1626-1633.

9. Lincoln, R.E.; Hodges, D.R.; Klein, F.; Mahlandt, B.G.; Jones, W.I., Jr.; Haines, B.W.; Rhian, M.A.; Walker, J.S. Role of the lymphatics in the pathogenesis of anthrax. J. Infect. Dis. 1965, 115, 481-494.

10. Ross, J.M. The pathogenesis of anthrax following the administration of spores by the respiratory route. J. Pathol. Bacteriol. 1957, 73, 485-494.

11. Cleret, A.; Quesnel-Hellmann, A.; Vallon-Eberhard, A.; Verrier, B.; Jung, S.; Vidal, D.; Mathieu, J.; Tournier, J.N. Lung dendritic cells rapidly mediate anthrax spore entry through the pulmonary route. J. Immunol. 2007, 178, 7994-8001. 
12. Russell, B.H.; Vasan, R.; Keene, D.R.; Koehler, T.M.; Xu, Y. Potential dissemination of Bacillus anthracis utilizing human lung epithelial cells. Cell. Microbiol. 2008, 10, 945-957.

13. Tournier, J.N.; Quesnel-Hellmann, A.; Cleret, A.; Vidal, D.R. Contribution of toxins to the pathogenesis of inhalational anthrax. Cell. Microbiol. 2007, 9, 555-565.

14. Guidi-Rontani, C. The alveolar macrophage: The trojan horse of Bacillus anthracis. Trends Microbiol. 2002, 10, 405-409.

15. Guidi-Rontani, C.; Mock, M. Macrophage interactions. Curr. Top. Microbiol. Immunol. 2002, 271, $115-141$.

16. Glomski, I.J.; Dumetz, F.; Jouvion, G.; Huerre, M.R.; Mock, M.; Goossens, P.L. Inhaled non-capsulated Bacillus anthracis in A/J mice: Nasopharynx and alveolar space as dual portals of entry, delayed dissemination, and specific organ targeting. Microbes Infect. 2008, 10, 1398-1404.

17. Sanz, P.; Teel, L.D.; Alem, F.; Carvalho, H.M.; Darnell, S.C.; O’Brien, A.D. Detection of Bacillus anthracis spore germination in vivo by bioluminescence imaging. Infect. Immun. 2008, 76, 1036-1047.

18. Glomski, I.J.; Piris-Gimenez, A.; Huerre, M.; Mock, M.; Goossens, P.L. Primary involvement of pharynx and peyer's patch in inhalational and intestinal anthrax. PLoS Pathog. 2007, 3, e76.

19. Lowe, D.E.; Ernst, S.M.; Zito, C.; Ya, J.; Glomski, I.J. Bacillus anthracis has two independent bottlenecks that are dependent on the portal of entry in an intranasal model of inhalational infection. Infect. Immun. 2013, 81, 4408-4420.

20. Hahn, A.C.; Lyons, C.R.; Lipscomb, M.F. Effect of Bacillus anthracis virulence factors on human dendritic cell activation. Hum. Immunol. 2008, 69, 552-561.

21. Hahn, B.L.; Bischof, T.S.; Sohnle, P.G. Superficial exudates of neutrophils prevent invasion of Bacillus anthracis bacilli into abraded skin of resistant mice. Int. J. Exp. Pathol. 2008, 89, 180-187.

22. Corre, J.P.; Piris-Gimenez, A.; Moya-Nilges, M.; Jouvion, G.; Fouet, A.; Glomski, I.J.; Mock, M.; Sirard, J.C.; Goossens, P.L. In vivo germination of Bacillus anthracis spores during murine cutaneous infection. J. Infect. Dis. 2013, 207, 450-457.

23. Lindeque, P.M.; Turnbull, P.C. Ecology and epidemiology of anthrax in the Etosha National Park, Namibia. Onderstepoort J. Vet. Res. 1994, 61, 71-83.

24. Turnbull, P.C.; Doganay, M.; Lindeque, P.M.; Aygen, B.; McLaughlin, J. Serology and anthrax in humans, livestock and Etosha National Park wildlife. Epidemiol. Infect. 1992, 108, 299-313.

25. Hugh-Jones, M.E.; de Vos, V. Anthrax and wildlife. Rev. Sci. Tech. 2002, 21, 359-383.

26. Dixon, T.C.; Meselson, M.; Guillemin, J.; Hanna, P.C. Anthrax. N. Engl. J. Med. 1999, 341, 815-826.

27. Tekin, R.; Sula, B.; Deveci, O.; Tekin, A.; Bozkurt, F.; Ucmak, D.; Kaya, S.; Bekcibasi, M.; Erkan, M.E.; Ayaz, C.; et al. Cutaneous anthrax in southeast Anatolia of Turkey. Cutan. Ccular Toxicol. 2015, 34, 7-11.

28. Gilliland, G.; Starks, V.; Vrcek, I.; Gilliland, C. Periorbital cellulitis due to cutaneous anthrax. Int. Ophthalmol. 2015, doi:10.1007/s10792-015-0057-7.

29. Doganay, M.; Metan, G.; Alp, E. A review of cutaneous anthrax and its outcome. J. Infect. Public Health 2010, 3, 98-105.

30. Ringertz, S.H.; Hoiby, E.A.; Jensenius, M.; Maehlen, J.; Caugant, D.A.; Myklebust, A.; Fossum, K. Injectional anthrax in a heroin skin-popper. Lancet 2000, 356, 1574-1575.

31. Booth, M.G.; Hood, J.; Brooks, T.J.; Hart, A. Anthrax infection in drug users. Lancet 2010, 375, 1345-1346. 
32. Powell, A.G.; Crozier, J.E.; Hodgson, H.; Galloway, D.J. A case of septicaemic anthrax in an intravenous drug user. BMC Infect. Dis. 2011, 11, 21.

33. Inverarity, D.J.; Forrester, V.M.; Cumming, J.G.; Paterson, P.J.; Campbell, R.J.; Brooks, T.J.; Carson, G.L.; Ruddy, J.P. Injectional anthrax at a Scottish district general hospital. Epidemiol. Infect. 2015, 143, 1311-1321.

34. Ascough, S.; Altmann, D.M. Anthrax in injecting drug users: The need for increased vigilance in the clinic. Exp. Rev. Anti-Infect. Ther. 2015, 13, 681-684.

35. Owen, J.L.; Yang, T.; Mohamadzadeh, M. New insights into gastrointestinal anthrax infection. Trends Mol. Med. 2015, 21, 154-163.

36. Hashemi, S.A.; Azimian, A.; Nojumi, S.; Garivani, T.; Safamanesh, S.; Ghafouri, M. A case of fatal gastrointestinal anthrax in north eastern Iran. Case Rep. Infect. Dis. 2015, 2015; doi:10.1155/2015/875829.

37. Beatty, M.E.; Ashford, D.A.; Griffin, P.M.; Tauxe, R.V.; Sobel, J. Gastrointestinal anthrax: Review of the literature. Arch. Intern. Med. 2003, 163, 2527-2531.

38. Mayo, L.; Dionne-Odom, J.; Talbot, E.A.; Adamski, C.; Bean, C.; Daly, E.R. Gastrointestinal anthrax after an animal-hide drumming event-New Hampshire and Massachusetts. CDC MMWR Wkly. 2009, 59, 872-877.

39. Friedlander, A.M. Anthrax: Clinical features, pathogenesis, and potential biological warfare threat. Curr. Clin. Top. Infect. Dis. 2000, 20, 335-349.

40. Abramova, F.A.; Grinberg, L.M.; Yampolskaya, O.V.; Walker, D.H. Pathology of inhalational anthrax in 42 cases from the Sverdlovsk outbreak of 1979. Proc. Natl. Acad. Sci. USA 1993, 90, 2291-2294.

41. Banks, D.J.; Ward, S.C.; Bradley, K.A. New insights into the functions of anthrax toxin. Expert Rev. Mol. Med. 2006, 8, 1-18.

42. Collier, R.J.; Young, J.A. Anthrax toxin. Annu. Rev. Cell Dev. Biol. 2003, 19, 45-70.

43. Leppla, S.H. Bacterial protein toxins. In Anthrax Toxin; Springer-Verlag: Berlin, Germany, 2000; Volume 145, Chapter 19, pp. 445-472.

44. Moayeri, M.; Leppla, S.H.; Vrentas, C.; Pomerantsev, A.; Liu, S. Anthrax pathogenesis. Ann. Rev. Microbiol. 2015, 69, doi:10.1146/annurev-micro-091014-104523.

45. Liu, S.; Moayeri, M.; Leppla, S.H. Anthrax lethal and edema toxins in anthrax pathogenesis. Trends Microbiol. 2014, 22, 317-325.

46. Leppla, S.H. Anthrax toxin edema factor: A bacterial adenylate cyclase that increases cyclic AMP concentrations of eukaryotic cells. Proc. Natl. Acad. Sci. USA 1982, 79, 3162-3166.

47. Leppla, S.H. Bacillus anthracis calmodulin-dependent adenylate cyclase: Chemical and enzymatic properties and interactions with eucaryotic cells. Adv. Cycl. Nucleotide Protein Phosphorylation Res. 1984, 17, 189-198.

48. Park, J.M.; Greten, F.R.; Li, Z.W.; Karin, M. Macrophage apoptosis by anthrax lethal factor through p38 map kinase inhibition. Science 2002, 297, 2048-2051.

49. Park, J.M.; Greten, F.R.; Wong, A.; Westrick, R.J.; Arthur, J.S.; Otsu, K.; Hoffmann, A.; Montminy, M.; Karin, M. Signaling pathways and genes that inhibit pathogen-induced macrophage apoptosis-CREB and NF-kappaB as key regulators. Immunity 2005, 23, 319-329. 
50. Cunningham, K.; Lacy, D.B.; Mogridge, J.; Collier, R.J. Mapping the lethal factor and edema factor binding sites on oligomeric anthrax protective antigen. Proc. Natl. Acad. Sci. USA 2002, 99 , 7049-7053.

51. Kintzer, A.F.; Thoren, K.L.; Sterling, H.J.; Dong, K.C.; Feld, G.K.; Tang, I.I.; Zhang, T.T.; Williams, E.R.; Berger, J.M.; Krantz, B.A. The protective antigen component of anthrax toxin forms functional octameric complexes. J. Mol. Biol. 2009, 392, 614-629.

52. Mogridge, J.; Cunningham, K.; Lacy, D.B.; Mourez, M.; Collier, R.J. The lethal and edema factors of anthrax toxin bind only to oligomeric forms of the protective antigen. Proc. Natl. Acad. Sci. USA 2002, 99, 7045-7048.

53. Nassi, S.; Collier, R.J.; Finkelstein, A. Pa63 channel of anthrax toxin: An extended beta-barrel. Biochemistry 2002, 41, 1445-1450.

54. Pittman, P.R.; Norris, S.L.; Barrera Oro, J.G.; Bedwell, D.; Cannon, T.L.; McKee, K.T., Jr. Patterns of antibody response in humans to the anthrax vaccine adsorbed (AVA) primary (six-dose) series. Vaccine 2006, 24, 3654-3660.

55. Baldari, C.T.; Tonello, F.; Paccani, S.R.; Montecucco, C. Anthrax toxins: A paradigm of bacterial immune suppression. Trends Immunol. 2006, 27, 434-440.

56. Duesbery, N.S.; Vande Woude, G.F. Anthrax toxins. Cell. Mol. Life Sci. 1999, 55, 1599-1609.

57. Stepanov, A.V.; Marinin, L.I.; Pomerantsev, A.P.; Staritsin, N.A. Development of novel vaccines against anthrax in man. J. Biotechnol. 1996, 44, 155-160.

58. Tournier, J.N.; Ulrich, R.G.; Quesnel-Hellmann, A.; Mohamadzadeh, M.; Stiles, B.G. Anthrax, toxins and vaccines: A 125-year journey targeting Bacillus anthracis. Exp. Rev. Anti-Infect. Ther. 2009, 7, 219-236.

59. Cote, C.K.; Rossi, C.A.; Kang, A.S.; Morrow, P.R.; Lee, J.S.; Welkos, S.L. The detection of protective antigen (PA) associated with spores of Bacillus anthracis and the effects of anti-PA antibodies on spore germination and macrophage interactions. Microb. Pathog. 2005, 38, 209-225.

60. Welkos, S.; Friedlander, A.; Weeks, S.; Little, S.; Mendelson, I. In-vitro characterisation of the phagocytosis and fate of anthrax spores in macrophages and the effects of anti-PA antibody. J. Med. Microbiol. 2002, 51, 821-831.

61. Welkos, S.; Little, S.; Friedlander, A.; Fritz, D.; Fellows, P. The role of antibodies to Bacillus anthracis and anthrax toxin components in inhibiting the early stages of infection by anthrax spores. Microbiol. 2001, 147, 1677-1685.

62. Ireland, J.; Hanna, P.C. Amino acid- and purine ribonucleoside-induced germination of Bacillus anthracis delta-Sterne endospore: GerS mediates responses to aromatic ring structures. J. Bacteriol. 2002, 184, 1293-1303.

63. Ireland, J.; Hanna, P.C. Macrophage-enhanced germination of Bacillus anthracis endospores requires gers. Infect. Immun. 2002, 70, 5870-5872.

64. Moir, A.; Corfe, B.M.; Behravan, J. Spore germination. Cell. Mol. Life Sci. 2002, 59, 403-409.

65. Moir, A.; Smith, D. The genetics of bacterial spore germination. Ann. Rev. Microbiol. 1990, 44, 5331-5553.

66. Guidi-Rontani, C.; Weber-Levy, M.; Labruyere, E.; Mock, M. Germination of Bacillus anthracis spores within alveolar macrophages. Mol. Microbiol. 1999, 31, 9-17. 
67. Cote, C.K.; Rea, K.M.; Norris, S.L.; van Rooijen, N.; Welkos, S.L. The use of a model of in vivo macrophage depletion to study the role of macrophages during infection with Bacillus anthracis spores. Microb. Pathog. 2004, 37, 169-175.

68. Omotade, T.O.; Bernhards, R.C.; Klimko, C.P.; Matthews, M.E.; Hill, A.J.; Hunter, M.S.; Webster, W.M.; Bozue, J.A.; Welkos, S.L.; Cote, C.K. The impact of inducing germination of Bacillus anthracis and Bacillus thuringiensis spores on potential secondary decontamination strategies. J. Appl. Microbiol. 2014, 117, 1614-1633.

69. Gatto-Menking, D.L.; Yu, H.; Bruno, J.G.; Goode, M.T.; Miller, M.; Zulich, A.W. Sensitive detection of biotoxoids and bacterial spores using an immunomagnetic electrochemiluminescence sensor. Biosens. Bioelectron. 1995, 10, 501-507.

70. Bradley, K.A.; Mogridge, J.; Mourez, M.; Collier, R.J.; Young, J.A. Identification of the cellular receptor for anthrax toxin. Nature 2001, 414, 225-229.

71. Scobie, H.M.; Rainey, G.J.; Bradley, K.A.; Young, J.A. Human capillary morphogenesis protein 2 functions as an anthrax toxin receptor. Proc. Natl. Acad. Sci. USA 2003, 100, 5170-5174.

72. Liu, S.; Crown, D.; Miller-Randolph, S.; Moayeri, M.; Wang, H.; Hu, H.; Morley, T.; Leppla, S.H. Capillary morphogenesis protein-2 is the major receptor mediating lethality of anthrax toxin in vivo. Proc. Natl. Acad. Sci. USA 2009, 106, 12424-12429.

73. Martchenko, M.; Jeong, S.Y.; Cohen, S.N. Heterodimeric integrin complexes containing betal-integrin promote internalization and lethality of anthrax toxin. Proc. Natl. Acad. Sci. USA 2010, 107, 15583-15588.

74. Wei, W.; Lu, Q.; Chaudry, G.J.; Leppla, S.H.; Cohen, S.N. The LDL receptor-related protein LRP6 mediates internalization and lethality of anthrax toxin. Cell 2006, 124, 1141-1154.

75. Bergman, N.H.; Passalacqua, K.D.; Gaspard, R.; Shetron-Rama, L.M.; Quackenbush, J.; Hanna, P.C. Murine macrophage transcriptional responses to Bacillus anthracis infection and intoxication. Infect. Immun. 2005, 73, 1069-1080.

76. Comer, J.E.; Galindo, C.L.; Zhang, F.; Wenglikowski, A.M.; Bush, K.L.; Garner, H.R.; Peterson, J.W.; Chopra, A.K. Murine macrophage transcriptional and functional responses to Bacillus anthracis edema toxin. Microb. Pathog. 2006, 41, 96-110.

77. Erwin, J.L.; DaSilva, L.M.; Bavari, S.; Little, S.F.; Friedlander, A.M.; Chanh, T.C. Macrophage-derived cell lines do not express proinflammatory cytokines after exposure to Bacillus anthracis lethal toxin. Infect. Immun. 2001, 69, 1175-1177.

78. Friedlander, A.M. Macrophages are sensitive to anthrax lethal toxin through an acid-dependent process. J. Biol. Chem. 1986, 261, 7123-7126.

79. Friedlander, A.M.; Bhatnagar, R.; Leppla, S.H.; Johnson, L.; Singh, Y. Characterization of macrophage sensitivity and resistance to anthrax lethal toxin. Infect. Immun. 1993, 61, 245-252.

80. Kim, J.; Park, H.; Myung-Hyun, J.; Han, S.H.; Chung, H.; Lee, J.S.; Park, J.S.; Yoon, M.Y. The effects of anthrax lethal factor on the macrophage proteome: Potential activity on nitric oxide synthases. Arch. Biochem. Biophys. 2008, 472, 58-64.

81. Pellizzari, R.; Guidi-Rontani, C.; Vitale, G.; Mock, M.; Montecucco, C. Anthrax lethal factor cleaves mkk3 in macrophages and inhibits the LPS/IFNgamma-induced release of no and tnfalpha. FEBS Lett. 1999, 462, 199-204. 
82. Pellizzari, R.; Guidi-Rontani, C.; Vitale, G.; Mock, M.; Montecucco, C. Lethal factor of Bacillus anthracis cleaves the N-terminus of MAPKKs: Analysis of the intracellular consequences in macrophages. Int. J. Med. Microbiol. 2000, 290, 421-427.

83. Popov, S.G.; Villasmil, R.; Bernardi, J.; Grene, E.; Cardwell, J.; Wu, A.; Alibek, D.; Bailey, C.; Alibek, K. Lethal toxin of Bacillus anthracis causes apoptosis of macrophages. Biochem. Biophys. Res. Commun. 2002, 293, 349-355.

84. Vitale, G.; Pellizzari, R.; Recchi, C.; Napolitani, G.; Mock, M.; Montecucco, C. Anthrax lethal factor cleaves the N-terminus of mapkks and induces tyrosine/threonine phosphorylation of MAPKs in cultured macrophages. Biochem. Biophys. Res. Commun. 1998, 248, 706-711.

85. During, R.L.; Li, W.; Hao, B.; Koenig, J.M.; Stephens, D.S.; Quinn, C.P.; Southwick, F.S. Anthrax lethal toxin paralyzes neutrophil actin-based motility. J. Infect. Dis. 2005, 192, 837-845.

86. O’Brien, J.; Friedlander, A.; Dreier, T.; Ezzell, J.; Leppla, S. Effects of anthrax toxin components on human neutrophils. Infect. Immun. 1985, 47, 306-310.

87. Wright, G.G.; Mandell, G.L. Anthrax toxin blocks priming of neutrophils by lipopolysaccharide and by muramyl dipeptide. J. Exp. Med. 1986, 164, 1700-1709.

88. Agrawal, A.; Lingappa, J.; Leppla, S.H.; Agrawal, S.; Jabbar, A.; Quinn, C.; Pulendran, B. Impairment of dendritic cells and adaptive immunity by anthrax lethal toxin. Nature 2003, 424, 329-334.

89. Tournier, J.N.; Quesnel-Hellmann, A.; Mathieu, J.; Montecucco, C.; Tang, W.J.; Mock, M.; Vidal, D.R.; Goossens, P.L. Anthrax edema toxin cooperates with lethal toxin to impair cytokine secretion during infection of dendritic cells. J. Immunol. 2005, 174, 4934-4941.

90. Cleret, A.; Quesnel-Hellmann, A.; Mathieu, J.; Vidal, D.; Tournier, J.N. Resident CD11 c ${ }^{+}$lung cells are impaired by anthrax toxins after spore infection. J. Infect. Dis. 2006, 194, 86-94.

91. Raymond, B.; Batsche, E.; Boutillon, F.; Wu, Y.Z.; Leduc, D.; Balloy, V.; Raoust, E.; Muchardt, C.; Goossens, P.L.; Touqui, L. Anthrax lethal toxin impairs IL-8 expression in epithelial cells through inhibition of histone H3 modification. PLoS Pathog. 2009, 5, doi: 10.1371/journal.ppat.1000359.

92. Kirby, J.E. Anthrax lethal toxin induces human endothelial cell apoptosis. Infect. Immun. 2004, 72 , 430-439.

93. Warfel, J.M.; Steele, A.D.; D’Agnillo, F. Anthrax lethal toxin induces endothelial barrier dysfunction. Am. J. Pathol. 2005, 166, 1871-1881.

94. Banks, D.J.; Barnajian, M.; Maldonado-Arocho, F.J.; Sanchez, A.M.; Bradley, K.A. Anthrax toxin receptor 2 mediates Bacillus anthracis killing of macrophages following spore challenge. Cell. Microbiol. 2005, 7, 1173-1185.

95. Averette, K.M.; Pratt, M.R.; Yang, Y.; Bassilian, S.; Whitelegge, J.P.; Loo, J.A.; Muir, T.W.; Bradley, K.A. Anthrax lethal toxin induced lysosomal membrane permeabilization and cytosolic cathepsin release is Nlrp1b/Nalp1b-dependent. PLoS ONE 2009, 4, e7913.

96. Cote, C.K.; van Rooijen, N.; Welkos, S.L. The roles of macrophages and neutrophils in the early host response to Bacillus anthracis spores using a mouse model of infection. Infect. Immun. 2006, 74, 469-480.

97. Cote, C.K.; Dimezzo, T.L.; Banks, D.J.; France, B.; Bradley, K.A.; Welkos, S.L. Early interactions between fully virulent Bacillus anthracis and macrophages that influence the balance between spore clearance and development of a lethal infection. Microbes Infect. 2008, 10, 613-619. 
98. Hanna, P.C.; Acosta, D.; Collier, R.J. On the role of macrophages in anthrax. Proc. Natl. Acad. Sci. USA 1993, 90, 10198-10201.

99. Lincoln, R.E.; Walker, J.S.; Klein, F.; Rosenwald, A.J.; Jones, W.I., Jr. Value of field data for extrapolation in anthrax. Fed. Proc. 1967, 26, 1558-1562.

100. Terra, J.K.; Cote, C.K.; France, B.; Jenkins, A.L.; Bozue, J.A.; Welkos, S.L.; LeVine, S.M.; Bradley, K.A. Cutting edge: Resistance to Bacillus anthracis infection mediated by a lethal toxin sensitive allele of Nalp1b/Nlrp1b. J. Immunol. 2010, 184, 17-20.

101. Cote, C.K.; Bozue, J.; Moody, K.L.; DiMezzo, T.L.; Chapman, C.E.; Welkos, S.L. Analysis of a novel spore antigen in Bacillus anthracis that contributes to spore opsonization. Microbiology 2008, 154, 619-632.

102. Brahmbhatt, T.N.; Darnell, S.C.; Carvalho, H.M.; Sanz, P.; Kang, T.J.; Bull, R.L.; Rasmussen, S.B.; Cross, A.S.; O'Brien, A.D. Recombinant exosporium protein BclA of Bacillus anthracis is effective as a booster for mice primed with suboptimal amounts of protective antigen. Infect. Immun. 2007, 75, 5240-5247.

103. Cybulski, R.J., Jr.; Sanz, P.; McDaniel, D.; Darnell, S.; Bull, R.L.; O’Brien, A.D. Recombinant Bacillus anthracis spore proteins enhance protection of mice primed with suboptimal amounts of protective antigen. Vaccine 2008, 26, 4927-4939.

104. Yu, L.H.; Cutting, S.M. The effect of anti-spore antibody responses on the use of spores for vaccine delivery. Vaccine 2009, 27, 4576-4584.

105. Welkos, S.L.; Cote, C.K.; Rea, K.M.; Gibbs, P.H. A microtiter fluorometric assay to detect the germination of Bacillus anthracis spores and the germination inhibitory effects of antibodies. J. Microbiol. Methods 2004, 56, 253-265.

(C) 2015 by the authors; licensee MDPI, Basel, Switzerland. This article is an open access article distributed under the terms and conditions of the Creative Commons Attribution license (http://creativecommons.org/licenses/by/4.0/). 